\title{
Comparison of host responses induced by Salmonella typhimurium infection in genetically resistant and susceptible mice
}

\author{
M. TAKAHASHI, T. USHIJIMA and A. SETO
}

Department of Microbiology, Shiga University of Medical Science, Otsu, Shiga, 520-21, Japan

\begin{abstract}
Summary. A/J and BALB/c mice differ genetically in their resistance to the facultative intracellular bacterium Salmonella typhimurium. We compared the responses of these strains of mice to a virulent $S$. typhimurium infection. BALB/c mice mobilised more peritoneal exudate cells in response to the infection than did $A / J$ mice $30 \mathrm{~h}$ after infection, but the increase in bacterial counts in the livers and spleens of BALB/c mice was 10 -fold higher than in $\mathrm{A} / \mathrm{J}$ mice. The response to Concanavalin $\mathrm{A}$ (Con $\mathrm{A}$ ) of spleen cells from BALB/c mice was depressed, and both $\mathrm{L} 3 \mathrm{~T}_{4}{ }^{+}$and Lyt-2 ${ }^{+} \mathrm{T}$ cell subpopulations were decreased following the infection, whereas the response to Con $A$ of $\mathrm{A} / \mathrm{J}$ mice was increased and the $\mathrm{T}$ cell subpopulations were not altered significantly. These results suggest that $\mathrm{A} / \mathrm{J}$ mice respond more actively to $S$. typhimurium infection than do BALB/c mice, and this may be related to the natural resistance of mice.
\end{abstract}

\section{Introduction}

Natural resistance of mice to Salmonella typhimurium is controlled by several genes; the Ity gene located on chromosome 1 is the major one. ${ }^{1,2}$ When susceptible $\left(I t y^{\mathrm{s}}\right)$ mice are inoculated with a virulent strain of $S$. typhimurium, even at a low dose, they die within a few days. It has been shown that the growth rate of $S$. typhimurium in Ity $y^{\mathrm{s}}$ mice is faster than in resistant $\left(\right.$ Ity $\left.^{\mathrm{r}}\right)$ mice. ${ }^{3,4}$ Several observations have led to the suggestion that the effector cells for Ity expression are the resident macrophages, ${ }^{5}$ but the mechanism of the genetic control is still controversial. ${ }^{4,6,7}$ In the short survival time after infection it is difficult to study the immune response of mice to the bacteria and many workers have used avirulent strains of $S$. typhimurium which can establish a more prolonged infection in Ity ${ }^{\mathrm{r}}$ and Ity mice ${ }^{8,9}$ However, it is thought that severe infection induced by a virulent strain may evoke different host responses or damage in Ity ${ }^{\mathrm{r}}$ and Ity $^{\mathrm{s}}$ mice. The present study was performed to explore the possible participation of other mechanisms besides the intracellular killing activity of macrophages.

\section{Materials and methods}

\section{Mice}

$\mathrm{A} / \mathrm{J}\left(I t y^{\mathrm{r}}\right)$ and BALB/c $\left(I t y^{\mathrm{s}}\right)$ mice were bred in our own

Received 27 July 1989; accepted 12 Sep. 1989. animal facility from breeding stock obtained initially from CLEA Japan Inc. (Aobadai, Meguroku, Tokyo 220-14). Mice were used at 6-8 weeks of age.

\section{Bacteria}

The virulent strain of S. typhimurium, C5, was obtained originally from Dr Janet Plant (St Mary's Hospital Medical School, London). Fresh cultures prepared by growing the strain in Heart Infusion Broth (Nissui) at $37^{\circ} \mathrm{C}$ for $24 \mathrm{~h}$ were used for all experiments. The number of viable cells was counted by plating samples on to Bromthymol Blue (BTB) Agar (Nissui). In our preliminary studies, the LD50 for Ity $y^{\mathrm{s}}$ mice given intraperitoneally (i.p.) was 10 bacteria and for Ity ${ }^{r}$ mice was $10^{3}$ bacteria.

\section{Kinetics of S. typhimurium replication in vivo}

Mice were inoculated i.p. with $2 \times 10,2 \times 10^{2}$ or $2 \times$ $10^{3}$ bacteria. One or 3 days after infection, the mice were killed and the livers and spleens were removed aseptically and homogenised in saline with a Teflon homogeniser. Test samples were diluted appropriately and then plated on to BTB Agar. After incubation at $37^{\circ} \mathrm{C}$ for $24 \mathrm{~h}$, the number of colonies was counted.

\section{Enumeration of peritoneal exudate cells}

Five mice in each group were inoculated i.p. with $10^{2}$ viable $S$. typhimurium C5 cells in $0.5 \mathrm{ml}$ of phosphatebuffered saline (PBS). After 6,30 or $54 \mathrm{~h}$, peritoneal exudate cells (PEC) were harvested in PBS and washed 
twice by centrifugation at $200 \mathrm{~g}$ for $5 \mathrm{~min}$. The cell pellet was resuspended in PBS and the cells were counted in a haemocytometer. Results are expressed as the mean number of total PEC and standard deviation (SD).

\section{Mitogenic assay}

Spleens of three mice in each group were gently forced through a stainless steel sieve and the homogenate was collected in PBS. Red blood cells were lysed with Trisbuffered $\mathrm{NH}_{4} \mathrm{Cl}, \mathrm{pH} 7 \cdot 5$, and the undissociated cells were allowed to settle for $15 \mathrm{~min}$ at $4^{\circ} \mathrm{C}$. The spleen cell suspension was adjusted to $2 \times 10^{6}$ viable cells $/ \mathrm{ml}$ in Click's medium ${ }^{10}$ supplemented $(1 \%)$ with serum from normal or infected mice and gentamicin $5 \mu \mathrm{g} / \mathrm{ml}$. Assays were performed in 96-well flat-bottomed plates (no. 3072, Falcon, Becton Dickinson, Grenoble, France). To each well was added $200 \mu \mathrm{l}$ of the cell suspension and concanavalin A (Con A, Sigma Chemical Co., St Louis, MO, USA) $1.25 \mu \mathrm{g} / \mathrm{ml}$. The plates were incubated at $37^{\circ} \mathrm{C}$ for $58 \mathrm{~h}$ in a humidified atmosphere with $\mathrm{CO}_{2} 5 \%$; $18 \mathrm{~h}$ before the end of incubation, $0.5 \mu \mathrm{Ci}$ of ${ }^{3} \mathrm{H}$ thymidine (specific activity $32 \mathrm{Ci} / \mathrm{mm}$ ) was added to each well in a volume of $5 \mu$. The cells were harvested on to glass-fibre filters with an automated cell harvester (Labo Science LM-101) and incorporated radioactivity was counted by a Packard Scintillation Counter (Model Tricarb 460CD). Each determination was made in triplicate.

\section{Immunofluorescence analysis of spleen lymphocytes}

Monoclonal antibodies against the mouse T-cell surface markers, anti-L3T4 and anti-Lyt-2, were the gift of Dr Masuda (Department of Immunology, Institute for Immunology, Kyoto University, Japan). The spleen cells were pelleted and resuspended at a concentration of $1 \times$ $10^{6}$ cells in $100 \mu$ l of PBS supplemented with sodium azide $0.1 \%$ and incubated with anti-L3T 4 antibody or anti-Lyt-2 antibody (each diluted 1 in 2) on ice for 30 $\mathrm{min}$. After three washings, cells were incubated with fluorescein isothiocyanate (FITC)-coupled rabbit antirat immunoglobulin (MBL; diluted 1 in 100) on ice for 30 min. Afterwards, cells were washed again three times and suspended in PBS for analysis by EPICS C (Coulter Co.).

\section{Results}

\section{Kinetics of growth of S. typhimurium}

Fig. 1 shows the numbers of bacteria in the livers and spleens of $A / J$ and BALB/c mice following i.p. inoculation of three doses of $S$. typhimurium. One day after infection, the population level of bacteria was practically the same in both strains of mice, but on day 3, the population of bacteria in BALB/c mice was 10 -fold or more higher than that in $\mathrm{A} / \mathrm{J}$ mice at doses of $2 \times 10^{2}$ and $2 \times 10^{3}$ bacteria.

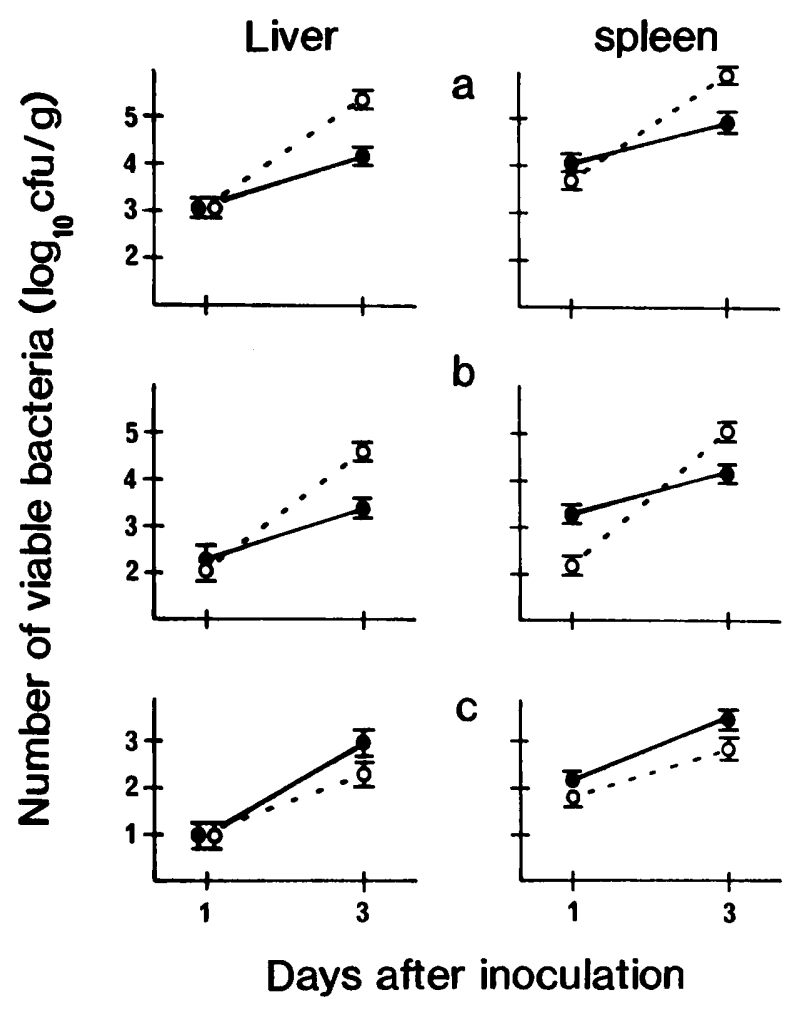

Fig. 1. Mean viable counts of $S$. typhimurium in the livers and spleens of $\mathrm{A} / \mathrm{J}(\mathrm{O})$ and BALB/c $(\mathrm{O})$ mice infected with $2 \times 10^{3}$ (a), $2 \times 10^{2}\left(\right.$ b), or $2 \times 10^{1}$ (c) cfu of $S$. typhimurium; bar $=\mathrm{SD}$.

\section{In-vivo accumulation of PEC}

The number of PEC of BALB/c mice increased to five times the pre-inoculation number by $30 \mathrm{~h}$ after inoculation of $S$. typhimurium, whereas the number of PEC of $\mathrm{A} / \mathrm{J}$ mice remained unchanged at this time. However, there was no great difference in the rate of accumulation of PEC between the two strains of mice $54 \mathrm{~h}$ after inoculation (table I).

\section{Mitogenic activity}

The response to Con $A$ of spleen cells from $A / J$

Table I. Recovery of peritoneal exudate cells from $\mathrm{A} / \mathrm{J}$ and $\mathrm{BALB} / \mathrm{c}$ mice after i.p. inoculation of $10^{2}$ viable $S$. typhimurium

Mean number $\left(10^{6}\right)$ of $\mathrm{PEC} /$ mouse (SD)

\begin{tabular}{ccc}
\cline { 2 - 3 } Time after inoculation $(\mathrm{h})$ & A/J & BALB/c \\
\hline 0 & $1 \cdot 8(0 \cdot 38)$ & $3.9(0 \cdot 82)$ \\
6 & $1 \cdot 7(0 \cdot 85)$ & $3.2(0.85)$ \\
30 & $1 \cdot 4(1 \cdot 2)$ & $20 \cdot 0(3 \cdot 6)$ \\
54 & $5 \cdot 4(2 \cdot 5)$ & $14.0(1 \cdot 2)$ \\
\hline
\end{tabular}




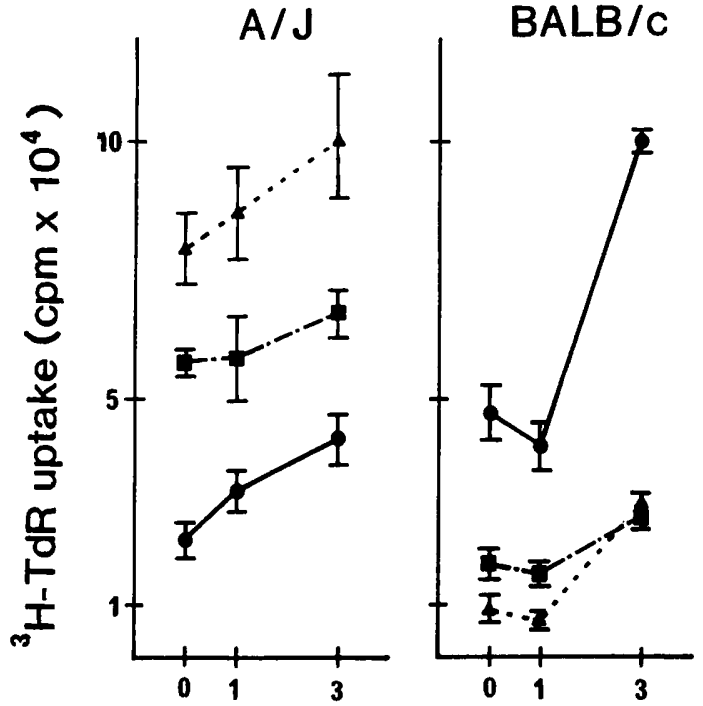

Day of collection of serum

Fig. 2. Proliferative activity in the serum and proliferative responses of pooled spleen cells from groups of three $A / J$ and BALB/c mice harvested $0(\mathcal{O}), 1(\boldsymbol{\Lambda})$ or $3(\square)$ days after inoculation of $2 \times 10^{2} \mathrm{cfu}$ of $S$. typhimurium, and cultured with serum harvested at 0,1 , or 3 days after infection. Each point represents the mean value; $b a r=S D$.

mice was enhanced as the infection advanced, whereas that of spleen cells from BALB/c mice was depressed 1 or 3 days after infection. Some serum factors promoting proliferative responses of spleen cells to Con A were induced by infection with $S$. typhimurium (fig. 2).

\section{Flow cytometric analysis}

In the spleen cells of BALB/c mice, $\mathrm{L} 3 \mathrm{~T}^{+}$and Lyt $-2^{+} \mathrm{T}$ cell subpopulations decreased with the course of infection, in particular the L3T4 ${ }^{+}$ subpopulation decreased to about $50 \%$ of that in the normal mouse. In $\mathrm{A} / \mathrm{J}$ mice these subpopulations did not alter significantly, although the Lyt-2 subpopulation increased a little (table II).

\section{Discussion}

Accumulation of phagocytes at local tissue sites is an important event in immunologically mediated host defence. When live $S$. typhimurium cells were inoculated i.p. into BALB/c mice, they recruited several times as many PEC as were mobilised in similarly treated $\mathrm{A} / \mathrm{J}$ mice $30 \mathrm{~h}$ after inoculation. However the rate of increase of $S$. typhimurium between 1 and 3 days after inoculation was 10-fold
Table II. L3T4 and Lyt-2 subpopulations in spleen lymphocytes

\begin{tabular}{|c|c|c|c|c|}
\hline \multirow{3}{*}{$\begin{array}{l}\text { Days after } \\
\text { inoculation } \\
\text { (days) }\end{array}$} & \multicolumn{4}{|c|}{ Percentage of spleen lymphocytes* in strain } \\
\hline & \multicolumn{2}{|c|}{$A / J$} & \multicolumn{2}{|c|}{$\mathrm{BALB} / \mathrm{c}$} \\
\hline & L3T4 & Lyt-2 & L3T4 & Lyt-2 \\
\hline 0 & $26 \cdot 3$ & $16 \cdot 6$ & $28 \cdot 5$ & $14 \cdot 1$ \\
\hline 1 & $25 \cdot 7$ & $18 \cdot 5$ & $17 \cdot 8$ & 8.7 \\
\hline 3 & 22.9 & $20 \cdot 3$ & $15 \cdot 9$ & $10 \cdot 0$ \\
\hline
\end{tabular}

* Data obtained by flow cytometric analysis of $5 \times 10^{3}$ pooled cells from three mice in each group.

higher in the spleens and livers of BALB/c mice than in $A / J$ mice. These findings suggest that BALB/c mice have an ability to mount an inflammatory response to $S$. typhimurium, but lack the ability of bacterial uptake or intracellular killing by phagocytes. Many in-vitro studies have shown that macrophages from Ity ${ }^{\mathbf{r}}$ mice have greater bactericidal activity than those from Ity $y^{\mathrm{s}}$ mice. ${ }^{11-13}$ Yet several reports and our present study have shown that no significant differences can be found in the growth of bacteria in the livers and spleens 1 day after infection between $I t y^{\mathrm{r}}$ and $I t y^{\mathrm{s}}$ mice, regardless of the size of bacterial inoculum. ${ }^{4,7}$ The reason for this discrepancy is not clear. It is possible that the natural resistance of mice may be determined by bacteriostatic rather than bactericidal mechanisms, and may require the participation of mechanisms other than the intracellular killing activity of macrophages.

It is assumed generally that immunodepression increases susceptibility to infectious agents. Some reports describe a correlation between the responsiveness of spleen cells to mitogens and the susceptibility of mice to $S$. typhimurium infection, ${ }^{14,15}$ but owing to the differences of mouse strains and bacterial strains used, results in these studies are not comparable. Deschens et al. reported that, in Ity $y^{\mathrm{s}}$ mice, there is marked depression of the proliferative response of spleen cells to $B$ and $T$ mitogens as a result of infection with a temperaturesensitive mutant of $S$. typhimurium; this was associated with an impairment of interleukin-2 production. ${ }^{15}$ We did a similar experiment with a virulent $S$. typhimurium strain and observed that the proliferative response of spleen cells to Con $A$ was markedly depressed in BALB/c mice 1 day after infection. By flow cytometric analysis, spleen $T$ cell numbers and the distribution of antigens such as Lyt-2 and L3T4 were similar in both strains 
of uninfected mice, but in BALB/c mice L3T4 ${ }^{+}$ and $\mathrm{Lyt}-2^{+} \mathrm{T}$ cell subpopulations decreased 1 day after infection. In contrast, in $A / J$ mice the proliferative response increased with an infection and these subpopulations did not alter. The depression of proliferative response was related not only to the decrease of $T$ cell numbers but also to the ability of the $T$ cells to respond to mitogen. There is also the possibility that increase of other cell types (i.e., macrophages) may suppress $\mathrm{T}$ cell responses. Evidence has been presented for the participation of both $\mathrm{L} 3 \mathrm{~T}^{+}$and $\mathrm{Lyt}-2^{+} \mathrm{T}$ cells in the adoptive transfer of resistance to listeria. ${ }^{16,18}$ In salmonella infection, both $\mathrm{T}$ cell subpopulations may be required for effective protection.

In this study we found a peculiar function of serum. When $\mathrm{A} / \mathrm{J}$ mice were infected with $S$. typhimurium, a factor potentiating proliferative activity of spleen cells to Con $A$ was induced in the serum and increased as the infection advanced. Serum from BALB/c mice obtained 1 day after

\section{REFERENCES}

1. O'Brien A D, Rosenstreich D L, Taylor B A. Control of natural resistance to Salmonella typhimurium and Leishmania donovani in mice by closely linked but distinct genetic loci. Nature 1980; 287: 440-442.

2. Lissner C R, Weinstein D L, O'Brien A D. Mouse chromosome 1 Ity locus regulates microbicidal activity of isolated peritoneal macrophages against a diverse group of intracellular and extracellular bacteria. $J$ Immunol 1985; 135 : 544-547.

3. Benjamin W H, Turnbough C L, Posey B S, Briles D E. Salmonella typhimurium virulence genes necessary to exploit the Ity $^{\mathrm{s} / \mathrm{s}}$ genotype of the mouse. Infect Immun $1986 ; 51: 872-878$.

4. Swanson R N, O'Brien A D. Genetic control of the innate resistance of mice to Salmonella typhimurium: Ity gene is expressed in vivo by 24 hours after infection. $J$ Immunol 1983; 131: 3014-3020.

5. O'Brien A D. Influence of host gene on resistance of inbred mice to lethal infection with Salmonella typhimurium. Curr Top Microbiol Immunol 1986; 124: 37-48.

6. Hormaeche C E, Harrington K A, Joysey H S. Natural resistance to salmonellae in mice: control by genes within the major histocompatibility complex. $J$ Infect Dis 1985; 152 : 1050-1056.

7. van Dissel J T, Stikkelbroeck J J M, Sluiter W, Leijh P C J, van Furth $R$. Differences in initial rate of intracellular killing of Salmonella typhimurium by granulocytes of Salmonella-susceptible C57BL/10 mice and Salmonella-resistant CBA mice. J Immunol 1986; 136: 1074 1080.

8. Nauciel C, Vilde F, Ronco E. Host response to infection with a temperature-sensitive mutant of Salmonella typhimurium in a susceptible and a resistant strain of mice. Infect Immun 1985; 49: 523-537.

9. Killar L M, Eisenstein T K. Delayed-type hypersensitivity and immunity to Salmonella typhimurium. Infect Immun $1986 ; 52$ : $504-508$. infection reduced the proliferative response a little, but serum obtained 3 days after infection augmented the response. We did not characterise the component in the serum responsible for this proliferative response, and do not know whether the factor participates in the natural resistance of mice. However, in $\mathrm{A} / \mathrm{J}$ mice the proliferative response of spleen cells and the production of the factor in the serum increased in parallel, and were maximal 3 days after infection.

The data presented above show that in $\mathrm{A} / \mathrm{J}$ mice infected with $S$. typhimurium, responsiveness of spleen cells is elevated in comparison with BALB/ c mice. Previous studies have emphasised differences in the ability for intracellular killing of $S$. typhimurium by resident macrophages. Possibly the resistance to infection with $S$. typhimurium might be determined by the interaction of various factors. The findings reported here shed light on another facet of the differences in the natural resistance of mice.

10. Katz-Heber E, Peck A B, Click R E. Immune responses in vitro II. Mixed leukocyte interaction in a protein-free medium. Eur J Immunol 1973; 3: 379-385.

11. Blumenstock E, Jann $K$. Natural resistance of mice to Salmonella typhimurium:bactericidal activity and chemiluminescence response of murine peritoneal macrophages. J Gen Microbiol 1981; 125 : 173-183.

12. van Dissel J T, Leijh P C J, van Furth R. Differences in initial rate of intracellular killing of Salmonella typhimurium by resident peritoneal macrophages from various mouse strains. J Immunol 1985; 134: 3404 3410.

13. van Dissel J T, Stikkelbroeck J J M, Michel B C, Leijh P C J, van Furth R. Salmonella typhimurium-specific difference in rate of intracellular killing by resident peritoneal macrophages from salmonella-resistant CBA and salmonella-susceptible C57BL/10 mice. J Immunol 1987; 138: 4428-4434.

14. Lee J C, Gibson C W, Eisenstein T K. Macrophagemediated mitogenic suppression induced in mice of the $\mathrm{C} 3 \mathrm{H}$ lineage by a vaccine strain of Salmonella typhimurium. Cell Immunol 1985; 91 : 75-91.

15. Deschenes $M$, Guenounou $M$, Ronco $E$, Vacheron $F$, Nauciel C. Impairment of lymphocyte proliferative responses and interleukin-2 production in susceptible (C57BL/6) mice infected with Salmonella typhimurium. Immunology 1986; 58: 225-230.

16. Kaufmann S H E, Hug E, Vath U, Muller I. Effective protection against Listeria monocytogenes and delayedtype hypersensitivity to listerial antigens depend on cooperation between specific $\mathrm{L} 3 \mathrm{~T}^{+}$and $\mathrm{Lyt}^{+} 2^{+} \mathrm{T}$ cells. Infect Immun 1985; 48: 263-266.

17. Czuprynski C J, Brown J F, Young K M, Cooley A J. Administration of purified anti-L3T4 monoclonal antibody impairs the resistance of mice to Listeria monocytogenes infection. Infect Immun 1989; 57: 100 109. 